\title{
Quality Education and Financing Challenges in Nigeria
}

\author{
Henry Ajagbawa \\ Doctoral Student with International School of Management, Paris and New York
}

\begin{abstract}
The world continues to be a dynamically changing place and the changes over the centuries have and would continue to challenge the teaching and learning process. Meanwhile a nation's vitality and commitment to economic development anchors on its Education strategy, the quality of schooling, and lifelong learning experience it provides the citizen amongst other vital developmental catalyst. Quality of education appear to have been south bound in recent years in Nigeria thereby challenging the substance of quality manpower development necessary for the development of the country. The purpose of the commentary essay is to highlight perceived gaps in the functionality of the educational system, specifically at the higher education level, to meet the developmental needs of Nigeria. The commentary focuses on the pivotal issues that underlie the disconnection including; curricula content and design concerns, pedagogic delivery methods, poor conditions of service for faculty, loss of self-esteem and dignity of teachers, poor education spendby government, strikes by teachers and students, and inadequate infrastructural and institutional support. The commentary suggest that finance is fundamental to quality education and requires urgent and concerted attention by society in view of government lack of capacity to continue to solely fund higher education, and specific recommendations are made.
\end{abstract}

Key words: Assessment Evaluation, Development, Education, Finance, Learning Outcomes

\section{Introduction.}

In the unfolding world where change has become natural, furious in pace, and mandatory but development optional, a nation's vitality and commitment to economic development anchors on its strategy on the quality of schooling (UNESCO, 2009) and lifelong learning experience it provides the citizen amongst other vital developmental catalyst. A definite nexus exist between education and development (WEF, 2014), and the axial connection between economic development and quality education is buttressed by Hanushek\& Wobmann (2007), and kolb (2005) who argued the efficacy of experiential learning to advancing development. Developed countries (DC) tended to have higher level of quality education in terms of learning outcomes achievement, better learning environment, education spend per capita, student teacher ratio, infrastructural and teaching aids, relevant basic and applied research outcomes, et al.

The world continues to be a dynamically changing place and the changes that have occurred over the centuries have challenged the teaching and learning process and would continue to do so. Even for the mostDCs, progressive enquiry continue to unravel the sociological dynamics of society and the need for paradigm shift to best practices in the sharing and transmission of knowledge for the development of society. We expect that the developing countries should especially pay attention to the changing dynamics of society to be able to forge dynamic educational system to meet the needs of the $21^{\text {st }}$ century world and beyond. A paradigm shift in knowledge building and transmission may be required to transmute to a comparable state of development as the first world.

The sociological framework of paradigm shift and stages of societal changes, developed by Rosado (1997) is instructive in understanding the functionality of the education system in tandem with the state of development of the society. The framework captures the time path of society's development, from the $18^{\text {th }}$ century agrarian economy, $19^{\text {th }}$ century industrial economy, the $20^{\text {th }}$ century information age and the $21^{\text {st }}$ century global village status of the world. The thrust of the framework facilitates genuine self-assessment of comparable state of development juxtaposed with the rest of the world on the one hand, and on the other hand an objective assessment of the relevance and functionality of the educational system in meeting the development needs of society

In the light of the models' characterisation most African countries would appear to be living anachronistically in the $18^{\text {th }}$ and $19^{\text {th }}$ century when juxtaposed with the rest of the world in terms of the level of economic development, institutional advancement, rule of law, position in the world league of higher education institutions especially in terms of meeting learning objectives and contributing to the world pool of relevant development directed research efforts to the human race. What this implies is that, African countries must situate their specific developmental needs and harness strategic resources in dealing with the challenges in a uniquely continental manner that bridges the consistency between the internal African environments with the rest of the world. 
Education is one key factor that disconnects the reality of the African developmental agenda and the transmutability to a developed status rests on the quality and functionality of the educational system in producing a learned population, addressing partly the leadership crisis and the leadership change process, respect for the rule of law and institutions, technological advancement and economic development. It would be empowering therefore to pursue an educational system where the construction of the pedagogical content and delivery methodologies adopted are in sync with country development goals and align with the dynamical sociological state.A functional and relevant education system to the development agenda of the African continent cannot depend strictly on imported education from the west but education that is contextualised to the local needs and aspirations of the people.

Education is a critical resourceto meet the manpower requirement for accelerated economic and technological growth (Bailey, et al, 2012), and has since substituted natural resource endowment as a source of development (Gylfason, 2001). Strategic resources of a nation comes from intellectual power of the mind rather than from natural resources and so true development in the $21^{\text {st }}$ century comes from empowering the mind of the people. Ironically, literacy rate (CIA, 2014) in Nigeria remain one of the lowest at $61 \%$ in Africa; Cameroon, Zimbabwe, Ghana, and Kenya at $62.5 \%, 84 \% 71 \%$ and $87 \%$ respectively, and Africa at the rear of world literacy.

Interestingly, some schools of thought continue to argue on the relevance and appropriateness of western education to the development of developing countries. Strategy wise, there is uniqueness in differentiation and the payoffs can be positively long term in nature, but the axiom, you cannot re-invent the wheel of progress is apt. All countries of the world benefit from the science and technology power house of western education, generating the physical development and new ideas on which modern civilisation seats. It is pointless to criticize the content of the technological advancement brought by western education when we should be focusing on contextualizing the whole process to our environment for rapid catch-up to the rest of the world.

Failure to contextualize education to the local environment in terms of content and delivery is an integral part of the challenges that have stymied educational development and accelerated the disconnection between education and economic development in Nigeria. There are legion of problems, but the decontextualization of education to local environment (Kigotho, 2014) has increasingly widened the distance between the educational outcomes and societal expectation, with implication on economic development. There are organic issues starting from the basic education level through to the tertiary level but this commentary focuses on tertiary education in analysing the axial forces of education and other development imperatives for economic development in Nigeria. By definition, economic development captures the concurrent development of all positive aspects of human endeavour

\section{Meaning And Purpose Of Education.}

The purpose of education is to create and sustain an enlightened mind that can elevate and progressively advance the touch points between human and environment through an inquiry predilection of society. This is consistent with Rosado's (2000) conceptualisation of true education; as the "harmonious development of the physical, mental, moral, and social faculties, the four dimensions of life, for a life of dedicated service" To educate therefore is the process of awakening the thirst for knowledge and a desire to develop the entire dimension of the human capacity. The symphonic slant between the mind (learning) and human environment is buttressed by Tagore (as cited by Singh, 2013) that"the highest education is that which does not merely give us information but bring our life in harmony with all existence.

Education is a derived Greek word which means "to lead out" In other words, the philosophical premise of education is the assumption of the latent state of the human faculty and the need for a process "to lead out" and manifest the latent perfection in man. Knowledge is presumed to exist in the mind but without form, the instructions(teaching and learning process) represents the friction required to ignite the body of knowledge, skills and mental capacities and help to give shape and structure to the cognitive capacity of the mind. Thus, the interaction of the mind with the environment unlocks the hidden treasure of nature given knowledge. Rousseau, the $17^{\text {th }}$ century philosopher posited that education is the child's development from within, and all efforts at true education should be to unlock that nature given cognitive capacity that is hidden in the soul of every human.

Consequently, the purpose of education as suggested by Rand (1982) is to "teach a student how to live his life-by developing hismind and equipping him to deal with reality. The training he needs is theoretical/conceptual. He has to be taught to think, to understand, to integrate, to prove. He has tobe taught the spirit and essentials of life-long learning as a lifestyle. Knowledge acquisition requires the training and development of an inquiry mind that leaves a human in a condition of continually asking questions and probing the status quo with a view to improving his environment and his relationship with it. The educational system 
that consistently delivers improved learning outcomes, enhances experiential learning, challenges critical thinking, and delivers solutions to mankind is deemed efficient.

Educationist are guided by philosophies which encapsulate their goals,purpose, structure, and design of curriculum, and delivery methodology of the teaching and learning process (Combs, 2010). Various philosophers like Plato, Pestalozzi, et al, have different educational philosophies as many other educationist today. The different perspective flows from differences on the aim and purpose of education by educationist. However, the axial pull on the various thoughts on education should satisfy certain base purpose and functions described as outcome of the education process; that education is a lifelong process of disquisition that facilitates the harmony of the four dimensions of life to the environment and that education is innate in the essence of the nature given cognitive capacities of human which is maximised when each person ultimately self-actualise.

The purpose of education relates to the fundamental goal of transmission of knowledge, skills, development and sharpening of the cognitive capacity, and character formation, and this represents the end product of the education process which is to create a learned and learning population (Yero, 2002). The functions of education on the other hand pertain to the other outcomes that may occur as a natural result of the process - by-products of schooling such as the natural process of applying knowledge learned into solving real life problems and affective moral values imprint, ingrained from the schooling process. This academic distinction between purpose and function of the education system at best can help schools put their main outcome focus in perspective and act as a guiding mission for the school. Functions are assumed to occur as a consequence of the purpose without directed effort while the purpose is the fundamental outcome desired and is effort driven.

\section{Education Outcomes.}

In developing the education policy of a country, significant thought must be given to what outcomes are fundamental to the development of the country and ensure those outcomes drive the policy formulation thrust and meaningfully integrated into the overall development plan. We present below a hybrid of the education outcomes as crafted by the World Economic Forum (WEF)on Education and Skills 2.0: New Targets and Innovative Approaches. TheWEFeducation outcomes are consistent with most generalised education outcomes. Overall, they approximate similar themes and representative of expectations from the education process.

\section{Outcomes}

*Impart the skills and capacities that people need to be productive members of the communities;

*Generate and promote the assimilation of new knowledge to spur socioeconomic, scientific, technological, and political advancement

*Promote social equity and cohesion and the legitimacy that comes from equal opportunity;

* Give people access to a broad swath of knowledge and ideas;

*Promote the study and development of culture and values as arts and the humanities;

*Inculcate the desire and ability to learn throughout life; promote lifelong learning

*Enhance critical and creative thinking;

*Promote acceptance and tolerance of difference and diversity;

*Develop media literacy and the capacity to effectively evaluate large amounts of often-conflicting information - a reflection of evolving needs in the 21 st century.

At the higher education (HE) level, each institution of higher learning is expected to craft a unique set of education outcomes consistent with the mission and philosophy of the school. Whilst generic and basic core courses are required for each field of study as may be prescribed by the relevant accreditation bodies, each institution must design its curriculum to suit and be in sync with its overall mission and goals. The accreditation system has the responsibility to affirm that institutions stay true to their mission. Nigeria has a unified accreditation process in higher education. The universities are accredited by the NationalUniversities Commission(NUC) while the Polytechnics and other Higher education institutions(HEI) are accredited by the Nigerian Board for Technical Education (NBTE).

\section{Accreditation In Higher Education.}

The purpose of accreditation in higher education include amongst others; 1) create a uniform currency and adaptable evaluation criteria for the measurement of quality of higher education learning. 2) Provide a basis for objective external validation of the institutional performance and focus on deficit areas for continuous improvement. 3) Help the HEI in resource allocation planning and re-appraisal of their efforts and strategies into needed and more focused areas. 4) Enable HEI to benefit from shared expertise, research knowledge, and innovative and critical thinking that shape educational policy and improve learning practices. 5) Create an easy credit transferability arrangement for students through common quality validation process across HEI. 6) Enable 
a platform for parents to make informed judgment on selection of schools to send their ward. 7) Help employers in head hunting to meet specific predetermined fit to job role specification.

The common themesof the accreditation function are that it offersHEIentrance information to parents, provide head hunting information to employers, and education spend information to government. The schools learn the right lessons on how to self-improve from the accreditation process and consolidate the quality validation process of HEI. Overall, accreditation provide assurance on the integrity of HE learning and a practical link betweenHE learning and research solutions to societal problems.HEI can mirror the needs of society and direct focus onto those areas (Lee Kuan Yew, 2000). The accreditation process can help in laying emphasis on the design and recalibration of the curricula structure and content in a manner that address the peculiar needs of the society.

The accreditation process as a tool in addressing national objectives may pay specific attention to a particular area of science, technology, and mathematics education relevant to leveraging the comparative advantage of that society. The relevant infusion of the areas of study in a uniform manner to HEI as an absolute minimum for accreditation may be one of the steps necessary to redirect attention to the critical areas amongst other fundamental support steps. You would expect, in a developing country especially, a burgeoning collaboration between the education ministry and the accreditation agencies in consolidating the functions of the accreditation process to meet predetermined education outcomes beneficial to society's economic and technological development.

One of the pivotal reasons for accreditation is to influence the performance outcome of students. By accreditation, we certify that the integrity of the faculty, instructional content and delivery methodologies, student support services, physical and financial resources as well as the existence of a quality enhancement program is in place, (SACS COC, CHEA, 2012) intact and sustainable in the HEI in a manner that outcomes of the learning process is of high quality and predictable. Therefore, one of the usefulness of the accreditation process is to stimulate and influence both the quality of its intake and the quality of its outcomes since the feedstock quality affects the quality of student outcomes.

The 2013 National Assessment Education Progress report, for example, consistently placed a country like Singapore ahead of the US, whereas, the country only recently transited from third world to first world status at the turn of the 21 century. Nigeria and Singapore shared a common third world toga in the early 1960's. While Nigeria remains educationally stagnant if not retrogressed, Singapore has outpaced most of the developed world educationally. This in part demonstrates the strong link between quality education and economic development. Questions need to be asked whether a causal relationship exist between the planning of the founding fathers and the results before us. The case of Singapore is not a mere happenstance!

The rancorous relationship between the universities, the universities commission and the education ministry reflects the lack of collaboration and defeat of the ideals of the accreditation purpose (ASSU, 2009). Overall, Nigeria must begin to think of the purpose of the accreditation process in terms of its relevance to societal development. It should affirm the appropriateness of the administrative configuration of the government controlled accreditation process as adequate for the educational development sought by the country (ASSU, 2009). It should seek answers on how the process can become prime in the activation process of other important variables in the education sector that would help shape the future values and development of society. The accreditation process must impact on all stakeholders.

\section{The Rhetoric Of Education Outcomes Assessment.}

The mode of measurement of education outcomes assessment in HEI in Nigeria remainthe term and end of year written examination. Observers are in agreement that the stylized education outcomes earlier noted remain a mirage. For example, the revised 1981 and 2004 national policy on education encapsulates the essence of the stylized education outcomes (Babarinde, 2012) but the realisation remain a challenge. Observers have noted that the education system is tipping to a dangerous new level of total loss of personal initiative in the learning process as lecturers by their conduct have endorsed rote memorisation as the learning mode, while students are challenged by a myriad of internal and external constraints.

For a few decades, it has been observed that quite a number of teachers have mastered the act of transmitting from text books, with or without context to the local environment and so cannot achieve meaningful and shared learning experience with the students. Deep and experiential learning is often promoted by the analogical learning means of metaphor which finds relevance to the local environment. Rather, re-gurgitation of notes provided in class, and often without context to local experience, has become the means of performance in examination. Exacerbating the situation is that the notes are frequently sold by the teachers, thereby limiting the scope of manoeuvrability of student outside the box. It is unlikely that the cognitive capacity of students are improved, critical thinking capabilities enhanced, appropriate and relevant skills imparted or lifelong learning culture imprinted on the students from such learning practices. 
Rote memorisation of jaundiced educational materials have thus become the basis of learning and knowledge transmission in most HEI resulting in the loss of the power and benefits of deep, experiential and observational learning. The initiatives of student in the learning process is stultified and deep learning by which students are totally immersed in the knowledge experience of the subject is no longer being tested and so motivation for self-improvement by student is lost. Rather the focus is on passing examination through and by whatever means possible.

With a dangerous trend like this, can we truly affirm that capacity/ability to think creatively is assessed in today's school? Towhat extent is the typical student heard and or his personal experience shared and used as a basis of consolidating lessons learned, Are students given the opportunity to recognize and evaluate different points of view? Are students even allowed to air different points of view in our higher education system? Are students taught skills and experiences that enhance understanding and appreciation of citizen rights and responsibilities? Arestudents taught the integrative link between historical facts and everyday life environmental experiences that would ultimately elevate their life? Finally, are students adequately prepared for the crossover to the real world after school? All the great education scholars, Pestalozzi, Kolb et al have validated these pivotal issues as critical to sound and quality education.

The consequences of rote memorisation and a pedagogy that constrains the intellect and creative ability to probe, think outside the box, and be inquisitive is manifesting in the economy at large. This coupled with the comparable low rate of HE enrolment in Africa is telling. Nigeria and indeed, most African countries have been unable to develop active scientific and engineering work force that can translate scientific knowledge to productive services in the local environment, even in the face of available scientific knowledge. Africaremain at the foot of the HE enrolment rate at less than 5\% (UNESCO, 2009) whereas some countries are inching up to over $90 \%$. Interestingly, most Asian countries which were at the same level of educational development with African countries by the second half of the twentieth century have since surpassed Africa on education outcomes achievement.

The imperialist excuse can no longer hold because many of these countries that have extricated themselves from the shackles of poverty and ignorance suffered similar colonial legacies like all African countries. Africans must resolve these developmental challenges. Scientific knowledge is in the public domain and transcend national borders (IIEP, 2007). The accessibility and use of the knowledge however depends on the availability and quality of the human capital. Other transitioning economies like Asian countries have creatively innovated on existing technologyto suit peculiar local realities. With this mind-set, the education process in Africa must be able to harmonise the environment with its human capacity to leverage the environmental opportunities for development of society.

\section{Moral, Parental And Other Stakeholder Input In Education Outcomes}

The transmission of moral and ethical values acceptable to society, and good conscience, to the next generation is a critical pivot of the education system outcomes, and self-esteem and efficacy (Bandura, 1997) is further strengthened from the right transmission of moral values. Learning is best consolidated from lived experience when the intellect interacts with the environment (Caine, Caine, McClintic\&Klimek, 2005). Therefore, regardless of the taught moral values in schools, students have a natural predilection to consolidate the learned and observed moral values and experiences that they interact with in their homes and social environment. If therefore, the environment is corrupt, the students are likely to imbibe, internalise, and integrate the celebrated values as the acceptable and learned norms and culture of the society.

Outlandish stories of bribe for examination scores, sex exchange for marks, sale of examination questions and all such sordid tales dominate the conversation on the level of moral degradation that the HEI have slipped into over the past few decades. Are the faculty principally responsible for this slip or the parents have their share of the blame in the context of parental responsibility? Corruption is an illegal and immoral act that entails two parties. If teachers want bribe, and parents are willing to capacitate their ward to give in to the demand, then parents have not only acted illegally and immorally but have equally failed in the responsibility of parenting.

Education involves the transmission of the right moral and ethical values to children by parents and this task ought to be performed by lived experiences. When parents fail to use opportunities like this to challenge the waywardness of faculty members, then, they have lost the twin chance of performing the moral duty of parenting to the children, and challenging the status quo of decadence in our higher education system. It is a collective failure. Parenting is also influenced by the power of influence of the social and cultural influences in our society such that children look up to seniors as role model. Therefore, collectively as influencers of behaviour of children, we dominate the formation process of the right cultural values of children by the very value system we celebrate and reward.

With the fear of possible challenge that the conversation is heading towards a monologue, we explore the possible rationale for the generally acknowledged degeneration of faculty of most higher education 
institutions in Nigeria. Observers have traced the degeneration of HEI faculty to the military incursion into the polity of developing countries like Nigeria. The quality has since been systematically decimated through lack of funding, and gradual demolition of the self-esteem of the teaching profession in Nigeria. Teachers of HEI over the years have been practically stripped of dignity and reduced to glorified beggars who at some extreme could hardly meet their family and social responsibilities. Research evidence exists that links self- esteem to qualitative educational offering in a country. UNESCO (2001) affirms this position from evidence in research work in Cuba and Korea.

The loss of self-esteem of HEI teachers, now grappling with physiological needs through trading in examination questions papers and lecture notes gradually facilitated the sharp decline in education quality in Nigeria. On top of this, most of the few remaining quality faculty members in the HEI were forced to join the bandwagon of the brain drain to the west thereby exacerbating the situation of academic staff shortage to run an efficient HE system. The agitation for better terms of service by the teachers have been on for a while now and aside some remuneration terms that are being met (ASSU, 2009), the bulk of the requests to deal with the HEI broken infrastructure, limited capacity issues, overcrowding continue to remain unmet.

As a first step towards revamping the higher education system, the emolument and general working conditions of faculty members must be elevated to a state of respectability that confers psychological boost of improved self-esteem. This restoration process represents an absolute minimum, amongst other factors, for the educational system to begin to gain traction in quality performance. In the intervening period, corruption of both faculty, student and parents hold sway and the realities of eking out a living dominates the motivational pull for the teachers who must continue to do what they must to survive in the cesspool of the damaging condition of no retreat no surrender by government and teachers.

The responsibility for influencing higher education outcomes lie as much with the parents as with the school authorities and the students. Education is not considered as a mere preparation towards an occupational life but a life-long learning experience that develops the human innate capacity throughout a life time of continuous self-improvement and reconstruction of experiences. It is the development of these capacities in the individual which enables the student to control his environment and fulfil his possibilities and meaning in life. Yes! Graduation gets us the right job but the real impact role is the preparation of the foundation for the life journey ahead. Financial reward ideally, is an integral part of the rewards of a quality education system but transcends to self-fulfilment, tooling for life-long learning aspiration, better informed member of society and an active change agent in the battleground of intellectual competition of the future.

A proper clarification of the personal values of student and the development of self-esteem should catalyse students toward self-actualisation on all the metrics of education assessment criteria. Societal values are challenged and not a few youth can disambiguate their personal values. Unsurprisingly, education to our teaming youth today is a "means to an employment end" or immediate personal financial glorification, and so no effort is applied in attainment of the functional outcome assessment criteria. Realistically and within the context of Nigeria where over $50 \%$ of the population live below the poverty line and over half of its graduate are unemployed or unemployable, can young graduates be faulted for their posture towards the essence of education. The human hierarchy of needs suggest that other needs will follow only when physiological needs of man have been met.

The same way the self-esteem of teachers have been shaken over the years, the students confidence and self-esteem in pursuing the ideals of education as a tool to opening up society's development have been curtailed by massive poverty permeating a larger part of the country. Students just want to graduate and get a job to escape the burning poverty and harsh living conditions challenged by extremely poor infrastructural support and high cost of living index. The rural urban migration has made matter worse and may remain unabated as long as the rural areas suffer the infrastructural neglect it has over the years. In spite of the tuition free higher education, some poor parents can hardly cope with the cost of maintenance of their ward and thus the pressure to get out of school ASAP and help with smoothening their financial challenges.

On account of poor pedagogue, overcrowding, poor student preparation, challenged faculty morality, many students have been alleged to connive with faculty to obtain degrees for which they have not satisfied the minimum requirements for the award of the degree. Anecdotally, some graduates cannot compete effectively with their foreign counterparts. Having conducted hundreds of entry level and management level interviews across the six geopolitical zones of the country over the years, I feel particularly sad at the quality coming out of the institutions of higher learning. Naturally, there are a few outliers who are particularly good in comparison to the general system. The life-long excitement of the learning process would appear to have been sacrificed for immediate economic gains, and sometimes for life-saving economic reasons for the extreme poor. 


\section{The Higher Education Score Card In Nigeria.}

The historical morphology of higher education is well documented and is not the focus of the commentary. Rather, a reflection on the state of higher education against comparable countries, and the pursuit of sustainable and quality higher education and the funding challenges remain the focus of this commentary. The country must validate a meaningful type of education it should be providingits youth and anchor the educational system on realism, otherwise Nigeria will continue the path of motion without action. What therefore is the state of higher education or how does the score card look like in Nigeria?

There are a total of 225 higher education institutions in Nigeria (Shu'ara, 2010), comprising universities and polytechnics. The combined student enrolment is about $1.326 \mathrm{~m}$, and the total faculty size is estimated at 48,610 . Nigeria has a population of 170 million people. Contextually, the US, UK Ghana, and Kenya have 4599, 162, 56 and 62 higher education institutions respectively, and a student enrolment of $17.5 \mathrm{~m}$, $2.34 \mathrm{~m}, 0.148 \mathrm{~m}$ and $0.241 \mathrm{~m}$ respectively (AUT, 2005, Montgomery, 2008, US, 2013, Gachie, 2013). Table 1 illustrates some comparative statistics amongst these countries as a basis of gauging the quality of higher education in these countries.

Table 1: Comparative Statistics On Higher Education

$\begin{array}{llllll} & \text { NIGERIA } & \text { KENYA } & \text { GHANA } & \text { UK } & \text { US } \\ \text { POPULATION (M) } & 170 & 44.35 & 25.37 & 63.7 & 318.1 \\ \text { NO OF HEI } & 225 & 62 & 56 & 162 & 4599 \\ \text { STUDENT ENROL (M) } & 1.326 & 0.241 & 0.148 & 2.340 & 17.50 \\ \text { FACULTY SIZE ('000) } & 48.61^{*} & 5.50 & 2.643 & 152 & 1540 \\ \text { EDUCATION/GDP (\%) } & 1.5 & 7 & 8.8 & 5.5 & 5.5 \\ \text { HCI RANKING } & 114 & 81 & 87 & 8 & 16 \\ \text { GCI RANKING } & 120 & 96 & 114 & 10 & 5\end{array}$

SOURCES: WEF, GCI AND VARIOUS (2012). * *Disagreement over the figure and some put it at less than 10,000

Post-independence stylized manpower development need as a necessity for economic emancipation buoyed most African countries to proliferation of HEI and by the turn of the second half of the twentiethcentury, government efforts have been complemented by private participation in HEI ownership (Adeogun, Subair, and Osifila, 2009). Aside the US, the population to HEI ratio in Nigeria is comparable to the UK, Kenya and Ghana. The incidence of a meagre $20 \%$ yearly admission capacity of eligible candidates into HEI isnot a mere consequence of the number of universities and polytechnics available in Nigeria, but also an indication of the absorptive capacity, preparedness, and depth of the HEIin terms of manpower, limiting delivery methods, and infrastructural capacity to accommodate more students. The faculty to HEI ratio is instructive, Nigeria, the US, and the UK at 216, 336, and 938 faculty members per HEI respectively. Ghana has 47.

The UK has about 162 universities and polytechnics with student enrolment at over $2.34 \mathrm{~m}$ thus giving an average of over 14,000 students per HEI. The average calculated for Nigeria is about 5,900 students, with the US, Kenya and Ghana having statistics less than Nigeria. Yet the UKHEI are able to cope better with students and produce better learning outcomes than their Nigerian and African counterparts. In comparison, the UK features in the international university ranking amongst the first 5 with good representation in the first 100 top world universities. Nigeria and most other African countries are not amongst the first 500 universities from our review. Nigeria makes up over $2 \%$ of the world population and put in context, over half of the students in the UK are foreign students from all over the world, with Nigeria making up $7 \%$ of the total university students in the UK.

Education is supposed to develop our creativity at solving local problems. Our HEI should have long developed and imbibe the e-learning methods of educational delivery. In thedeveloped world, a significant part of the learning interaction is achieved through the electronic platform, whether the learning approach is face-toface or e-learning. This enhances the level of information diffusion and the physical infrastructure and material cost to running schools can be better managed, synchronised amongst the competing student resource in the educational process. IT infrastructure cannot be an excuse. Nigeria has the highest internet access reach in Africa and connectivity has become relatively easier with the dawn of mobile telecommunication.

UNESCO (2009) recognises education as a means toward fostering economic development. The indexes of education spend as a proportion to the GDP provides an indication of the seriousness attached to education by a country as a vehicle of development. Consistently, most OECD countries record minimum of $4.5 \%$ and as much as $10 \%$ as education spend on GDP. Kenya, Ghana, UK and the US have 7\%, 8.8\%, 5.5\% and $5.5 \%$ respectively as ratio of education spend on GDP. Nigeria is at $1.5 \%$. Clearly, it would appear that the country is not taking education as seriously as other comparable countries. The future and destiny of a nation dependon the quality education it provides its youth. The Human capital index (HCI) reported by UNESCO unsurprisingly confirm the trend. The index reports the tri concepts of educational training and development, health; physical and mental, of its people and lastly the employability of its graduates. Nigeria is ranked at 114 while Ghana and Kenya are far better ranked at 87 and 81 respectively. 
There is consistency of evidence on the dismal outcomes from the education system in Nigeria. The education spend supports the supposition. The Human capital index computed by UNESCO affirms the southward slope, the un-employability of an average HEI graduate in Nigeriaare all compelling evidence of the state of the education system today. The cost of imported education from all over the world is estimated at over $\$ 3 \mathrm{~b}$ annually, clearly this is an avoidable drain on scarce foreign reserve (Abayomi and Arenyika, 2014). It is no longer strange to find Nigerians schooling all over West African Countries in addition to the more fashionable West. Did I mention that the global competitiveness index also ranked Nigeria behind most of the neighbouring countries? The index synthesises many other factors aside human capital but the themes resonates across.

Yes! As we have medical tourism being put together in Dubai so also neighbouring countries are latching into the failed educational system, advertising, and propositioning the youth for better education across the border. We have read stories of sub-standard educational facilities et al provided by some of these schools across the border, yet our youth continue to seek education outside, out of necessity. I recall as a young man in the seventies and eighties how Ghanaians were made bout of ridiculewith "Ghana must go bag "episode and encouraged toreturn home at a time of great depression in the then Ghana. Apparently, they have since put their act together and now exporting education to Nigeria. As a university student in the early eighties, foreign students from across Africa, including some Southern African Countries and West African Countries were on campus with us. Now the educational standard of virtually all these countries have surpassed Nigeria, which has since included education into its insatiable importation menu.

Talking about foreign students bring to mind the revenue potential from this source. In the same way we are losing foreign reserves to countries across the world like the US, UK, Singapore, UAE, Malaysia, Ghana et al, we could also plan to revamp the education system as a potential foreign exchange earner in the future. In the UK for example, discriminating fees are charged against foreign students compared to the locals, yet this has not deterred foreigners from seeking education from the UK. By the way, Nigerians make up 7\% of the total university enrolment population in the UK. People around the world would always pursue excellence, wherever they may be offered or at whatever cost.

Singapore, a country poor in natural resource endowment, has become one of the world leading HEI destination, underpinning its strategic developmental focus on the axial forces of the transportation hub, financial hub and education hub, and has since moved from third to first world by all attributes of economic development. Other countries like UAE, Qatar, et al have made education a pivotal part of the economy and a hub in the region. By 2020, it is estimated that there will be over $7.5 \mathrm{~m}$ international students across the world (UNESCO, 2009), and education will remain one of the fastest growing industry in the world. Education is now globalised with active alliances with bigger brands from the west in the form of offsite campuses across Asia. Systematically, quality is being strengthened and brand consolidated. What lessons can we take away from these trends?

Statistics indicate that the UK has $1 \%$ of the world population but generates at least $13 \%$ of the world research and academic publications amongst other great academic and scientific feats. Nigeria has missed out on the potential of making the nation the academic Mecca of the sub Saharan Africa region or at least the immediate West Africa axis. A few schools of excellence might have upped the ante and put us on the right path to developing a veritable educational hub for the West African axis in the first instance and beyond. A possible and potential source of foreign reserves, but we will leave the issue of funding until later sections of the commentary. Would active alliances fast track the process or a full paradigm shift is required for a catch up with the rest of the world.

VIII. Employment, Employability, And The Social System.

One of the critical goals of higher education for a developing economy like Nigeria is to fast track the training and development of Skilled and proficient workers to manage the economy; from the factory to private enterprise, and government. The level of manpower required must possess problem solving capabilities, decision making attributes, ethical and strong moral values, and critical thinking orientation in general. This is one area the educational system has failed to live up to expectation. UNESCO reports that less than $20 \%$ of the graduates produced today in developing countries have the appropriate training and skills to be productively engaged. Hence we are likely to have unemployment rate running to $80 \%$ for graduate workers, principally because they are unskilled while we have severe shortage of skilled workers at the graduate level.

A very ironic situation, where we have plentiful graduates in supply, yet shortage of skilled manpower leading to unemployment of labour and under-employment of other complementary physical resources necessary for development. This paradox mirrors the manifestation of the quality of education the nation isproviding its youth, and an inhibition to development. Employers will confirm that the training cost to converting the finished products from the HEI to usable material for the workforce is steep. Even more worrisome is the UNESCO prediction that by 2015 less than $16 \%$ of most sub Saharan African countries would 
have higher education. UNESCO predicted $80 \%$ and $60 \%$ for Singapore and North America. We are a year from the prediction and things havenot changed much from the worrisome and apparently self-fulfilling prediction.

Experts have recommended entrepreneurial training at the HEI and possibly inclusionas a core course to prepare the youth for future engagement and transition to the real world. Internship and apprenticeship are also recommended while a level of early career counselling is a must to guide and prepare the youth for early career direction. The national youth service corps as it operates today does not serve the purpose even though it can be worked on to ease the shocks of transition to work life for the young graduates. Government and private schools, as a matter of national education policy should explore how it can integrate the concept of internship into the curriculum of HEI, while practical entrepreneurship courses and career counselling support provided tothe schools.

The private sector must see this as a national call to duty and be ready to accommodate these interns for training purposes. I am often amazed at the level of engagement of interns in foreign land, how serious they are engaged, trained on the job and in the process the work values and ethos are systematically transmitted to the next generation and indeed the cost of transition from school to the work force would be easier for all. Anecdotally, most HEI students (especially from the polytechnics) sent for internship in Nigeria are often confronted with rejection and spend a larger part of the year searching for a place of assignment. It must be viewed as a PPP project by the organised private sector on the one hand and government agencies on the other.

Pedagogic delivery methodology could be a contributory factor in student effective attainment of the outcomes assessment criteria. First, HEI teachers are not appraised and evaluated for outcome effectiveness by students they teach. Observers have noted that some HEI teachers may appear a couple of times in a semester and there are no in-built control mechanism to enforce his obligations to school and students. As a matter of importance to uplifting the standard of teaching, the teachers must be subjected to regular independent and anonymous student evaluation in the class room and the evaluation results used as one of the bases of appraisal for the teachers.

Second, starting from the seminar mode of pedagogic delivery; be it in science or humanities, students are encouraged to prepare to lead in a lecture arrangement and a question-answer session employed to extract deep knowledge and promote intense preparation from students. Classes are sometimes stratified on basis of criteria that stimulates deep discussions. What this does for the educational system is to cultivate in students the imperative of professionalism and serious preparation for tasks, and also prepare students to understand the different sides of arguments, be intelligent enough to accept and respect the other side of the argument while forming consensus. An educational system that teaches respect for different points of view is one that promotes social cohesion and equity.

One of the challenges of our political system today is that of an incongruously divisive and un-cohesive partisanship that is intolerant and lack respect for each other. As leaders, we should continuously educate ourselves so we can elevate our game and improve the system. We can cross over to the seeming ideal of mutual respect and tolerance where the other side of the argument must be heard and respected. We don't have to agree but we must respect the other argument and perhaps leverage on the divide for better overall position. We must let our education work for us all around and we must see each opportunity as teachable experience where our children should soak in the lived experience which must meaningfully compare with the theoretical hand-out we give to them at school.

Learning is facilitated in an environment of relaxed alertness provided by both faculty sufficiency and capacity, and the appropriateness of the physical infrastructure (Caine, Caine et al, 2005). Some of the reasons adduced for the poor quality of education in Nigeria are the challenging environmental and faculty situation. Naturally, the most important ingredient in higher education is the quality and quantity of the faculty, the quality and relevance of its curriculum to its environment and the mission of the HEI. In this light, I have noted some disturbing trends. First, the development of the curriculum seems to have been frozen and the content of what is taught in most schools is akin to the Stone Age, yet we are supposed to compete globally. In my view curricula aredesigned, redesigned and changed to align with changes in the immediate and global scene, and in alignment with the needs of the various stakeholders like employers et al (Rosado, 1997). In some clime, stakeholder interaction outcomes are used as a means of alignment of practical input to the redesign of the curriculum (City University, 2012).

The second observation is the "business as usual "attitudeof the Education administrative and supervisory agencies. Till this age application for HEI set up is constrained with request of proof of ownership of minimum land acreage. We have evidence of excellent foreign schools with small shop that would embarrass our requirement. I am unable to relate the relevance of that requirement to the quality of the education to be served, at this age and time. We need to understand that education has gone beyond brick and mortar and is practically at the click of a button. We need to restructure our administrative arrangements surrounding the educational system in tandem with the reality of education delivery in the $21^{\text {st }}$ century. And this is likely to attract quality entrepreneurs and experienced educationist and make the educational system more competitive in 
terms of offering. Across the world, there is a persistent transition to private ownership of tertiary education as government can no longer sustain HEI alone.

Grandiose physical and imposing structures do not make a HEI, even though I must admit, add to its prestige and beauty. Our clamour for physical size for registration of a school when a high rise structure can be built on one acre to house a world class school;would then appear anachronistic. Even at that, most of our schools especially the public ones have huge structures which cost of maintenance presents a drain on its increasingly scanty resources. The structures are now mostly dirty, unkempt, dilapidated, and embarrassingly un-hygienic and broken from wear and tear and lack of maintenance. Indeed the learning environment can be a challenge to both student and instructors alike and this cut across all the tiers of the education system.

The picturesque evidence of broken infrastructure; poor classrooms, broken or lack of adequate classroom desk, absence of teaching aids, and poor learning environment; students sitting on the floor/standing to receive lectures, incredible studentto teacher ratio, and unmotivated teachers are all eloquent testimonial of the infrastructural decay in our classrooms and the dysfunctional teaching and learning environment. Little is required to motivate the youth out of the hassles of $\mathrm{HE}$ in environment as this. Increasingly, youths are dissuaded from education in the face of the difficult learning environment and the scotching unemployment that awaits them on graduation. A functional education system should provide options that address the constraints faced by graduates by focusing on the life-long enlightenment and self-development functions of higher education.

In reality students must not be programmed to believe they must work for industries and Government. Entrepreneurial studies need to be introduced into the school curriculum to ensure that graduates appreciate the path they must follow as they prepare to get out of school. This is beside the massive preparatory work Government must embark on to provide the support required for entrepreneurial minded youths to flourish as self-employed. Research evidence have indicated that stimulating and developing entrepreneurial behaviour have significant impact on economic development and the methods for stimulating and encouraging entrepreneurial activities are well documented.

The need for developing the ICT framework as a basis of development, and delivery of curriculum content has been recognised in Nigeria. The Minister of Communication at the WEF on Education in 2014 alluded to the School Access program running concurrently with the Teachers development component and the part funding of the schemes by the universal service provision fund. Connectivity and Access to devices were identified as some of the challenges facing ICT deployment as an educational delivery method. The focus of government is at the basic and secondary education levels.

The higher education institutions to a larger extent have imbibed the ICT technology at the personal student level. Connectivity and access is almost a givenamongst substantial number of students of tertiary institution. The challenge might be an acceptable policy framework, procedures, structural and physical resource availability, and teacher readiness to commence the effective deployment of ICT as a means of curriculum content preparation and delivery. Given the comparative inefficient utilization rate of our HEI in terms of student intake, this area deserves urgent resolution by the HEI. Government has nothing to do with this and each HEI should co-opt and leverage the private sector capabilities to commence the transition to efficient level of elearning ASAP.However, government would need to stimulate private sector investment towards achieving a becoming ICT infrastructure level.

Indeed, this is an era of plentiful information but little knowledge and the challenge is how to convert the massive information flows to embedded and applicable knowledge in the hands of students. Teachers would need to be trained and encouraged to transit to a more e-learning environment as a strategic way of taking $21^{\text {st }}$ century education to citizens as well as reducing cost of education in the long run. The e-platform is recommended, and as a complement to the traditional face-to- face delivery method. They reinforce each other. The appropriateness of curricula content however is another matter entirely. Pedagogic relevance to society is a function of the mission of the school system, defined by the school administrators. The pedagogue and the design of the curricula content must reflect the needs and aspirations of society. The delivery should anchor the cultural context of the particular society for effectiveness of learning. Education must work for society and facilitate development and the case of Singapore, UAE, and Qatar are good examples

Significant lessons can be learned from economies that have transited from third to first world in the twenty first century like Singapore. The planning process involved multiple focuses on education, transportation and financial sector development as a strategy to development. In a resource poor country as it was, it leveraged on its leadership competences to achieve a world class education, financial, and transportation hub status. The UAE has similarly adopted the transportation hub as a development strategy and other development strategies in education and medical tourism is following suit. How can Nigeria concurrently develop its financial and transportation industry as the African hub while building up its educational fortress to sustain and develop these markets in the next decade? Ghana is becoming the transportation hub for the West African Axis already amongst others, while Kenya is inching into the financial hub role. The banking sector assets to GDP ratio is a good example of financial development status of Kenya (70\%) in comparison to (30\%) in the African space. 


\section{Constraints And Inhibitions Of The Education System.}

There are several factors that affect the quality of education in terms of the content, delivery, learning, and application of knowledge. These factors include endogenous and exogenous factors. The endogenous factors are critical issues embedded in the school and learning process that are within the control of the school system and internal stakeholders. We have discussed most of these considerations in preceding sections but generally entail factors as quality of teaching, poor instructional methods; rote learning, maintenance of discipline, poor teaching aids like subscription to educational magazines, continuous training and development of teachers, and lack of scholarship opportunities offered by the schools to extreme indigent students.

But the bulwark of issues is the exogenous factors which define constraints that are external to the school control but are pivotal pillars for the delivery of quality education. These factors include poor education spend, lack of holistic and integrated education policy thrust, corruption and embezzlement at all levels of the education spectrum, industrial actions of teachers and strikes by students, poor teacher training, poor reward system and motivation. Others include culture and celebrated value system, poor research funding, lack of commercialization windows for local innovation and disconnect between industries and citadel of higher learning.

A Particularly disturbing external constraint to higher education learning in Nigeria is the quality of the feedstock going into the university system. The three tiered education system is universal across the world and there is a quality dependence relationship between one tier of education and the other. The feedstock of one tier is the finished product of the lower tier. The dependencies of the three levels have significant implication for the quality and orientation of the eventual output of the educational system. Consequently, our evaluation of the effectiveness of the educational system and its effectual link with society's need must take root from the three tier for clarity.

Firstly, a spill over drawback to quality education is poor nutrition that students confront from the basic education to the tertiary education level. The brain is a highly metabolic organ that facilitates learning when well fed (Dangcalam, 2011). Try rigorous brain work on an empty stomach like many children across the landscape have had to endure. At the HEI level, how can we integrate the significance of good nutritional valueinto the educational system starting from the design of the hostels and infrastructure to cater for kitchenette for students to be able to arrange decent meals or support with vegetables and fruits supply at subsidized rates. The HEI can themselves participate and engage their agriculture departments for production of fruits and vegetables for sale to a ready market in the campus. The farm would be commercially viable business that contributes to the resources of the school while at the same time providing field experience for the undergraduates to serve out apprenticeship programs.

Nutrition remains a huge challenge to children at the early school age especially at the primary education level. The need for cheating and examination malpractices may not be unconnected with poor capacity to learn borne out of poor nutrition. No scientific study has been done to support this yet but presents an interesting preposition. The level of examination malpractice at the secondary school level has attained a notoriety of its own over the years and teachers, parents and students are all active partakers in the scam. The secondary school examination pass rate at GCSE is put at $20 \%$ overall. There is a cultural undercurrent at the heart of this cancerous part of the education system that needs the attention of all.

Some students have allegedly refused taking part in cheating on grounds of their upbringing while others are actively seekingways to cheat. Parents have significant moral guidance role to play while teachers must be seen to eschew alleged economic benefits; selling question paper, promoting cheating in exam halls or looking away while students cheat at exams. Be that as it may, the result is half baked inputs into the HE system that compromises the likely quality coming out of the HE system. Observers have noted that some teachers have resigned from the profession on account of their moral inability to continue to handle the organised scam of examination malpractice at the secondary school level.

It is possible that little steps are beginning to appear in the horizon. Some private schools with affordable feestructure to the middle class are now offering education with comparable international standard. Some also provide a window of scholarship to the low income group and other less privileged students to access quality education. We must note and celebrate such schools as The Day WaterManCollege and James Hope College. The various Jesuit schools by the Catholic mission is another good example. These schools and a few others provide a glimpse of sound educational continuity to be bequeathed to the next generation.

We mentioned earlier the issue of learning environment as critical to effective and deep learning. Most institutions of higher learning have decelerated to glorified secondary schools where the physical infrastructure is at best embarrassingly squalid, but most worrisome is the absence of effective teaching aids and materials. Lack of books or obsolete books in library, lack of access to e-library, and lack of subscription to academic and intellectual magazines are the signpost of most HEI. The e-learning platforms through which lecturers can communicate to class and encourage engagement between teachers to student, and student to student et al, remain a mirage in most HEI. Classrooms themselves are uncomfortable and with the prevalent student to 
teacher ratio, intolerable classroom temperature, and dilapidated and inadequate furniture, et al. Deep and effective learning will continue to be arduous and a mirage until these concerns are addressed.

Accreditation is another serious reason for lack of uniform and consistent quality in Nigeria's HEI. In earlier sections, we itemized the purpose of accreditation. The review shows for example that no business school in Nigeria is accredited to any of the several international accreditation agencies across the world. The need for international accreditation is to provide assurance that our schools are producing graduates of comparable international repute and quality. Ghana has at least one business school with such international accreditation. It is possible that many other fields of human endeavour lack world class accreditation. The ASUU has been entangled with the FGN on refining and redefining the accreditation process to instil a better level of professionalism and enhance the quality process coming out of it (ASSU, 2009). It has been motion without action so far as the accreditation process remains dogmatic at best. Conferment of international accreditation means the graduates from Nigerian universities can stand shoulder high with graduates from the rest of the world.

It is on record that employers for some time now have discriminated against degrees awarded by Nigerian HEI. Shell, Chevron et al (Chikwen, 2006) for example have a mandatory one year training program for Nigerian engineering graduates while their counterparts from other countries are exempt from the training. Firstly, we should congratulate the company for undertaking the pain and cost to do this as it could decide otherwise. This is one of the preparatory staff training programs undertaken by companies that spiral cost of doing business in clime like this. Surely, this should border all stakeholders of the education system. Secondly, stakeholder engagement by the HEI as a means of redesigning the curriculum and other change expectations to meet stakeholder's needs would help in addressing this negative trend.

\section{Financing Institutions Of Higher Learning.}

Amongst the entire drawback to a functional higher education system, finance stands out as fundamental. The government spend of GDP is a measure of the quality of education, and this spend is spread across the three tier of education with evidence of decreasing spend on higher education globally. While most OECD countries are operating at the neighbourhood of $10 \%$, the US at $7.3 \%$, and Ghana at $8 \%$, Nigeria is barely spending $1.5 \%$ of its GDP on education. Nigeria also fall short of the UNESCO recommended spend of $26 \%$ of national budget. The current education spend of the national budget is $10.7 \%$ with the best recorded in 1952 at 17\% (Adeyemi, 2011).

This shortfall in financing education is further exacerbated by the socialization of education in Nigeria, where higher education is presumed a social good and should be offered freely by government. The massification of higher education coming out of the increasing awareness and private demand for higher education, inflationary push on the cost of higher education, globalisation and transferability at the higher education level, the EU in particular following the Bologna accord, have all contributed to the escalation of cost of higher education which has outpaced government fiscal revenue sources to fund same (UNESCO, 2009). The situation has challenged both government and HEI in terms of offering quality education, meeting basic research funding requirement, provision of teaching aids, and competitive emolument structure to lecturers amongst other issues.

Government spend on higher education has been on a tailspin for the past decades (Akinsanya, 2007)with a gradual substitution from dominant government funding to internal funding of higher education. The sustained GDP spend on education has been on basic and secondary education rather than higher education. In the EU the proportion of university funding coming from tuition has increased from a meagre $4 \%$ in 2000 to over $50 \%$ for some HEI across the board. In the US tuition fees constitute $60 \%$ and $80 \%$ of university funding for public and private universities respectively. In Nigeria, Federal universities are exclusively funded from fiscal sources as tuition fees are prohibited and the proportion of other sources to its total revenue ranges between $2 \%$ to $20 \%$ for different HEI. Most state government attempt to introduce tuition fees have been met with stiff resistance that has left government crawling back into its shell.

Other sources of funding for HEIaside tuition fees and government grants and subvention include specific research funding to meet national objectives, contract research, consultancy services, commercial ventures, endowment fund, gifts and donation, PPP, and investment incomes (Bell, 2006). For most Nigerian HEI, the sources of funding are over $90 \%$ dependent on fiscal sources of Government. In particular, mention must be made on the role of government in funding research as a basis of breaking new scientific and technological grounds for development. The governments of the OECD countries fund $72 \%$ of university research cost (UNESCO, 2009). Further, the level of collaboration between the industries, government and the leading research universities is instructive for developing countries to leverage on.

The personnel cost of universities for example are exclusively funded by Government. The government Education Trust Fund support some specific capital projects in the universities. The total block grant appropriated by Government to the National Universities Commission for capital projects for the 27 Federal 
Universities between 1998 to 2007 amounted to N47B (Okojie, 2014). This averages N4.7B per year earmarked for capital projects annually for Nigerian universities and N174M (approximately $\$ 1 \mathrm{M}$ ) per university annually. In the face of a broken infrastructural system that requires a total and systematic overhaul, this allocation would appear damaging to the higher education system.

The squalid state of our higher education institutions, the lack of teaching aids, the outdated and obsolete facilities suggest that we require new financing models to escape this mess. As a first step however, government should put the university in a "catch up" state. Government must commence a Marshall plan to overhaul the infrastructural state of the HEI before they can effectively have a new start. Any action short of that would be ineffective, unproductive and unsustainable, as the critical government intervention is a mere catch-up to the base level at which the HE system should be operating. Everyone is mindful of the awesome responsibility of government today in curbing and handling the security challenges and other vital infrastructural demands of society but the education sector, more than any other sector, requires the most urgent attention for too many reasons that has attendant medium to long term sustainable developmental benefits.

\section{Some Thoughts On Financing Higher Education In Nigeria.}

Some very critical issues come to the fore. First, government allocation to higher education continue to dwindle, second, allocation to capital projects is insignificant to meet the needs of a $21^{\text {st }}$ century research oriented HEI needed forthe technological andeconomic development of the country, and lastly, the financing interface between the private sector and HEI appear under mined. Meanwhile, citizens are averse to tuition fees and every attempt by government to introduce tuition has been stoutly rejected, a catch-22 situation. The people are unwilling to pay fees, public funding of HEIcontinue to decelerate. The consequences onHEI is not farfetched, hence the rapidly declining quality of education in the country.

It would appear that most countries of the world, including Nigeria, have keyed into public funding of basic and secondary education in consonance with the UNESCO (WCEFA, 1990) declaration on mandatory basic education. What most governments have maintained is the inability of government to effectively fund higher education exclusively. Using N2M (Two Million Naira) as unit student cost of funding qualitative HE in Nigeria (Babalola, 2014), the national budget spend on HEI will amount to N2.6Trillion which approximates $56 \%$ of the national budget against the current budget spend on the three tier of education at $10.7 \%$

Certain damaging facts come out of these statistics. First, the total spend on the three tier of education at N493B in the 2014 budget is not anywhere near what is required to fund HEI alone at N2.6Trillion. Secondly, the education budget spend at $10.7 \%$ is not enduring against an average of $24 \%$ in comparable African countries like Ghana and Ivory Coast. Even if UNESCO recommended 26\% were to be attained or government devotes $50 \%$ of national budget to education, it would be insufficient to meet the funding needs of the three tier of the education system. Here lies the funding dilemma and the need for shared funding responsibility of the HEI system between the government and the private sector

Indeed, it is becoming apparent that government can no longer sustain the funding of HEI exclusively. Global trend is beginning to reflect this paradigm shift in HEI. For example, private funding of public universities is $50 \%$ and $60 \%$ in the EU and US respectively. On the other side of the divide, citizens view free education as one of the very few means of the resource redistribution function in an environment of pervasive income inequality. On the basis of the deteriorating corruption index of the country, citizens insiston the judicious application of scarce funds to better quality education otherwise frittered away by corrupt government practices. The statistics however indicate that even if there were to be purity in government, it would be impossible for government to exclusively fund HEI if comparable qualitative education is the objective.

Research evidence provided by Udoh (2007) supports the position of socialization of education. Parents and teachers pooled in the research suggest non-payment of school fees or any commercialisation exercise in HEI. They rather recommend the provision of scholarship, checkmatingof fraudulent practices in the university system to curb resource wastages, and advancing scientific breakthroughs. The level of scientific breakthrough via inventions and innovation is poor and so HEI may not be able to improve their funding position from this source. The quality must first improve to give impetus to this source as a potential scientific and economic power. The scholarship provision is consistent with the general thrust of our recommendation as would be explained shortly.

The argument is one that is not about to be won by either side. A cancerous tumourdetected early enough before malignancy, requires surgical operation to excise the intrusion from the body but what most doctors will tell you is that a lifelong healing process of a well-balanced life style is the ultimate cure and prevention of the problem. Therefore, our deep-seated moral and economic problem is not about to be cured overnight. This particular government did not create it but can start the healing process. Clear steps to deal with the issues must however be manifest. We cannot however wait for the total resolution of our moral and economic problems before we fix our education issues which in part define whether we will continue to be in the comity of developing countries or relapse to the Stone Age. 
The point being made here is that, all sides must be ready to sacrifice, and imbibe best practices evolving across the world. Higher education as the sole responsibility of government is no longer sustainable and indeed becoming unfashionable across the developed and developing world. It is the collective responsibility of all stakeholders, and the schooling outcomes we desire can only be achieved when higher education institutions are well funded. And how best do we achieve this. A middle ground of socialisation of education as demanded by citizens and privatisation as insisted by government may help deal with this problem while simultaneously, national objectives of technological growth is pursued for accelerated industrialisation of the country.

As an aside, there is always a level of wastefulness that comes with free service, either on the side of the providers or on the side of the receivers and this defies state of development of a country. This logic define the relative state of efficiency of the government universities and the private owned. For as long as higher education is free, the requisite value attached to it may not be realised. There is a social expectation for the acquisition of higher education, which in itself is good but a functional alignment between our private educational expectations and the requirement for technological and economic development seemsdisconnected. The economy is in severe shortage and need of trained craftsmen and technically sound professionals, yet we produce graduates who are unemployable, underemployed, and unemployed.

As a first step to fund the "catch up state" of HEI in Nigeria, the government may consider a "one time" tertiary development tax fund imposed on both corporate and personal tax payers, to be managed by private fund managers. We are not unmindful of the extant education tax fund, but every emergency situation requires unusual and creative solution. The private sector are co-beneficiaries of the education system and the cost of conversion of the HEI products to usable inputs in the businesses can be avoided or reduced substantially if funds can be raked in one time to enhance the quality of the educational system. The assurance required is that the fund should be managed by independent private fund managers under a trust deed that is well controlled and monitored.

On a continuing basis, a two prong funding strategy may evolve. First, the equivalent of a sovereign education trust fund, which should receive seed fund from both the tertiary education trust fund and the sovereign national fund, should be created. Eventually, the accumulated fund in the tertiary education trust fund is transferred to this fund for private sector lead. The signpost to efficiency in the management of the fund would be the appointment of international and local fund managers to independently manage the fund for the benefit of funding the tertiary education system. Subsequently, the fund should independently attract endowment, accrue investment gains and effectively manage the physical infrastructure development of the universities, the research direction in alignment with national needs, and help in shaping, through funding efforts, the curricula focus of the HEI system.

On a second note, discriminating pricing policy will facilitate an allocation mechanism that would ensure that the children of the low income group are as privileged to attendHEI as the children of the high income group, using a policy frame work that would accelerate the technological development of the country, deepen better resource control and corporate governance structure in the HEI by insisting on improved HEI accountability, and forcing or directing manpower allocation to the needed areas for development.

The policy process starts with the identification of the professions and disciplines thatare critical to urgent economic, scientific, and technological development of the country, tagged "development disciplines". The demand-supply gap of these critical areas is ascertained and a work program to fill the gap on a long term planning basis of 10 to 15 years in the first instance is agreed on. The ascertainment of the structure of the work force gap at the university, polytechnic and other professional vocational institutions of higher learning provides the basis for the introduction of a discriminating fee pricing structure to direct the allocation of students to the various fields for economic and technological development.

The suggestion is that full scholarship should be provided for all students in the "development disciplines "by government and or the HEI. Every other area of study not immediately classified as "urgent development discipline" would be made to pay full fees. This pricing structure would cut across the universities, polytechnics and vocational institutions of higher learning. It is expected that the fees collected would complement and or pay for the scholarship offered to students in the priority development disciplines. Therefore, indigentstudents desirous of higher education must be prepared to go into disciplines that are needed urgently by society. Those who insist on other areas of study must be prepared to foot the bill. Fiscal revenue must be tied to urgent economic and development need of society.

Discriminating pricing is an effective tool for promoting equity in the provision of social services like education. Universities in the UK charge averagely over $200 \%$ to $300 \%$ more for foreign students. The extras help in leveraging a good funding basis for the quality higher education provided in the UK. The fees paid by student in the "non-development" areas provide the funding buffer to subsidize the students of the development areas under scholarship. This way, better funding level is assured to sustain the provision of better quality of higher education. Research evidence by Udoh (2007) points out that parents are disagreeable to fees, but surely, 
a discriminating fee policy as suggested meets the expectation of parents, as the window to free higher education continue to exist, while quality is enhanced, and development needs of society promoted.

In arrangements like this, priority higher education areas become pretty competitive. Competition unleashes superior performance. Only the brightest and committed would be admitted into these areas and the bright students who insist on other fields of study are encouraged to do so. There is evidence on how engineering and mathematics education helped to turn the development tide in China and other Asian countries, where every home practically became a workshop of production or research of some sort. The very basis of industrialization lies in the development of foundries and fabrications capabilities. We have reached a point where we must turn our backyards to industries and become a producing country and the educational system must help to redirect our priorities and scale to optimum development goals. And like every sound policy measure, the policy must be phased to accommodate the passage of the current crop of students and to prepare parents and students alike over a 5 year period to the commencement of the policy.

It is important to note that the selection criteria of who goes to where depends on capacity to pass the entrance examination and other qualifying criteria as may be set by the HEI and does not challenge us with the economic status of the student, as that may be difficult if not impossible to ascertain in today's Nigeria given the paucity of economic data and earning power of people outside the organised private and government sectors. Fees should however be collected from the rich if sufficient data exist to easily pursue this direction. Otherwise, rich or poor kids have equal opportunity to get free education in the "development disciplines" as rich or poor kids have the right to choose to go to other fields of human endeavour to anchor their studies. The Government and HEI scholarship programs offer free education with a caveat that only relevant education to immediate and urgent societal need would be provided for free. Others must be paid for.

It is pertinent to point out that the role of government is direction setting in a dynamic economic system. For example, in deciding the constitution of the development disciplines, government may specifically look outside the "box" of science and technology and frame certain other disciplines that would train manpower for the preservation of national culture; dance, folklore, cultural displays, artefacts et al, that appear threatened and being eroded by foreign cultural influence. Most cultural groups and the young folks in the rural areas that appear to hold the fabric of these cultural norms are seeking alternative and empowering livelihood in urban areas and the transmission of these norms are endangered. Introduction of disciplines in vocational schools that can structure an effective transmission mechanism of these cultural norms over time has national social identity significance and economic long term benefits. Partly, the objective of achieving a high HE rate for the country is ensured while a strongly focused and functional HE system is built over time. Tourism potential may be upped in the long term by such directed policy thrust.

Statistics suggest that only $20 \%$ of university applicants get admitted in Nigeria. A programme that offers encouragement to students who are unable to attain the qualifying entrance standard of the universities, but who are equally talented in the qualifying disciplines, should be instituted to draft such students to pursue studies at the polytechnic and other vocational schools in the development disciplines. Full scholarship would be allowed to these group of students while others in "non-development disciplines" must pay the fees. The determination of the "development profession" is a function of the planning process that must be done from time to time to align with the identified manpower need of the economy.

Significant privatization of higher education will bolster the funding capacity of HEI and hopefully result in better overall productivity in terms of learning outcomes and research results to further economic growth. Frequent strikes by students and industrial actions by lecturers are known corollary of the funding dilemma in the HE system, and partly the source of the quality produced from the HEsystem. It is on record that the products of the HEI are discriminated against in Nigeria by multinationals for apparently internal quality issues. Embarrassing as it may, it calls for urgent, fundamental, and genuine review of the pedagogical content, delivery, assessment, and assessment evaluation processes along with the funding resolution drive.

Resources of government can best be ploughed into areas of enabling the environment for the generation of goods and services that would make the economy thrive better. Education is just one of the several factors that generates infrastructural and institutional capabilities of a nation for rapid development. Government cannot therefore devote all of its resources to funding higher education and even if it wished to do so, it just does not have the capacity to achieve. Private funding remains the solution or at best a hybrid. Government must be seen to engage in the upliftment of other key enabling and capacity enhancing sectors like electricity generation and distribution, good road network, and pursuance of other environment enabling factors like institutional improvement.

XII. Other Considerations In The Mix.

Efficiency comes from the maximisation of the positives and the minimisation of the negativesand this is typified in a corporate by the revenue and cost functions. In HEI, the objective function is the maximisation of the higher education outcomes which includes the learning outcomes, research findings, innovations and 
inventions, promotion of scholastic and lifelong learning society et al, while cost of the offering is kept as low as possible. The mix of considerations which would enable the maximisation of these outcomes are as critical as the provision of funding for HEI if efficiency is to be enhanced. We discuss a couple of these considerations;

Moody (2013) have identified several cost containment strategies to facilitating a better funding arrangement for HEI while also accentuating their main teaching and research focus. First and most importantly, the HEI must drive specialization and not necessarily be everything to everyone. Some HEI can be research biased while others are teaching biased. The mission of the HEI should be so clear on this count and provide a functional compass to direct efficiently the business of the HEI. Agreement on the area to focus will deepen specialization and give impetus to the actualisation of the core objectives of HEI while cutting cost and achieving a better overall efficient learning and research environment.

Cost containment and overall efficiency can also be aided by centralisation and shared service arrangement. All support activities of HEI should be streamlined to work as a single unit and providing shared corporate services to the institution. For example, operating different campuses requires having several units of corporate support services with significant cost implications. How can we bring all campuses together to a single location eventually to share services and cost in the medium to long term. And in the short run, how can we leverage information technology, scale economies, and advanced operations management techniques and processes to ensure functions are not duplicated and cost are kept at the most optimum level. In an increasingly competitive world for scarce resources, the need for optimisation and cost containment requires special focus and dedicated cost and management accountant teams to drive the process. Accountability can also be strengthened in Nigerian HEI by self-imposed and self-directed corporate governance standard and by the use of forensic auditors at certain periods

Programmatic review to reflect core competences and promote specialisation is another means of assuring better quality from HEI. A typical HEI in Nigeria run significant number of courses, and some may not be optimal in terms of commercial viability if the HEI were to be commercially ran. Collaboration amongst Academic leadership on how each HEI may streamline some courses that lack critical student mass to warrantcontinuation, while mutual understanding between the HEI to take on the relevant courses is forged. Student exchange and transferability cannot be a problem if all HEI were to submit themselves voluntarily to similar accreditation processes. The level of duplication of the overall HE system may be reduced if programmatic reviews are encouraged at the highest professional level of collaboration amongst the HEI.Comparable centres of excellence may emerge from programmatic reviews, collaboration and healthy competition.

New and technology friendly delivery method is changing the way education is facilitated today. HEI are encouraged to invest in Information technology (IT) infrastructure and the human skill set that together help in creating knowledge based workers for the $21^{\text {st }}$ century. Research evidence from Mansell, Stein, Mueller and Montalvo (2008) supports this position. The internet revolution for example has changed the way knowledge is shared, skills learned and technical infrastructure used. IT is a source of competitive development for a country, subject to its construct, diffusion approach and utilization (Madon, 2000; Avgerou, 2010). In banking the comparative estimated transaction processing cost per delivery channel is $\$ 0.20, \$ 0.90$, and $\$ 4.0$ via the internet, ATM, and Brick and mortar channels respectively. The same relative cost structures will hold for educational delivery modes and expectedly, a gradual migration to the e-learning mode would crash the cost of the HE system.

It can be taken for granted that the e-learning platform is cheaper, but the arguments against this mode relates to the issue of quality and interaction effect in the learning process. Before the internet, distance learning delivery mode, such as delivery by post, had been in existence. The internet has simply pushed the frontier of distance learning to the internet mode which may be real time synchronous or asynchronous. The level of interaction amongst student is not even impeded in the IT based learning mode as experts have suggested that students can and do progress at their own pace and without the distraction of social interferences and personal inhibitions like shyness, domination of class by a few, et al. This is not in any way suggesting the substitution of the HE face to face delivery mode with e-learning, but to note the huge benefits accruing from the e-platform and the need for gradual migration, while both are used complementarily.

Regional consolidation of leadership may also accrue cost benefit along with knowledge sharing and best practices promotion amongst others. In the same way as companies consolidate for growth and efficiency without impairment to their operating models or quality of their finished product, we could possibly bring together under one umbrella a group of contiguous HEI to be managed by common leadership. This reduces the cost to administration while freeing faculty members to substantive academic work. The average student size of Nigeria Universities is less than 6,000 while in some advanced countries like the UK, it is over 14000. This means that using student population as a means of measuring administrative stretch and capacity utilization, we could actually do with some measure of leadership consolidation to the overall improvement in management quality and academic robustness in our HEI. 
The use of tenured and untenured academic staff requires further review. First, the active infusion of professionally qualified lecturers' inHEI will breach the theory-practice gap in our institutions and reduce the time to market of our graduates. It would also result to reduction of cost to the HEI as untenured staff have less overall emoluments than the tenured academic staff. In business education, the accrediting bodies typically provide a mix of academically qualified and professional qualified staff that each program should carry. This can be introduced to the physical sciences, engineering, and related fields where technical leaders in industries with certified competences in specialised areasare courted toshare their knowledge in a structured manner with students. The learning outcomes for the HEI will be improved, the functional fit of graduates improved, and the cost structure of the HE system reduced if this arrangement is encouraged.

Overall, the HE system would need to be more commercially oriented in terms of seeking new markets to improve their capacities, improving on student intake by improving their delivery methodologies, use more efficiently their idle resources like letting out unused or underemployed properties and engaging in PPP projects with corporates within and outside the HE system (Amobi, 2013). Commercialisation of research findings should be given further impetus through robust collaboration with external stakeholders. HEI must actively expand their endowment activities as avirile source of funding. Schools like Harvard Universityhave endowment fund in excess of \$25Billion and continues to strengthen its revenue base.

The tertiary education trust fund has been a reliable source of funding for HEI since the enactment of the ETF law in 1993 as revised. By 2011, just over N500B has been collected with N128B collected in 2011 alone, a significant improvement that underscores the need for continuous improvement in collection. The fund has been applied to funding research, infrastructure development, academic journals, training of teachers, et al. While the fund has been applied to improving education over the years, the country still suffers from endemic quality issues across the board. We reiterate our earlier comment on the transfer of the fund management to independent private fund managers operated under a trust deed.

Global competitiveness depends on the quality of education and attempt must be made to showcase some quality coming out of Nigeria. In this wise, it might be a progressive idea to do a pilot run of quality enhancement program on say, the 4 oldest universities in the country. The Sovereign Education Trust Fund (SETF) to be convoked, would devote a significant part of it resources, say over the next 5 to 10 years and bring the 4 designated universities up to world class institutions as a starting point of compassing the country into the world education map. Active collaboration between the industries and the HEI must be deliberately cultivated by the ministries of education, and industries, through sharing of knowledge and research orientation and application.

\section{Conclusion.}

Development Economics have indicated such mix of factors as leadership, education, technology, financial development and cultural issues as key ingredients to development. Education however, stands out because of the affective capacity on the other factors. Education eventually influences the level of technological development, affects the level of enlightenment and process of leadership selection, pace of financial development, and influences both cultural norms that stand as institutional bottlenecks to development. We live in a vastly changing world that leaves us with no option than to rapidly respond and or stimulate change in order to manage our environment better. Indeed, change is mandatory but decision to develop is optional. Development does not occur from mere happenstance but requires deliberate plan, design and actionable decisions to move a nation forward.

Education in Nigeria has collapsed to an embarrassingly low level that every single household that can afford foreign education have included education to the growing list of imported consumption. The importation bill of education from Ghana alone is purported to be in excess of $\$ 1 \mathrm{~B}$ annually while globally the importation bill is estimated at over $\$ 3 \mathrm{~b}$. The annual importation bill of education is in excess of the total annual budget spend on education. As a nation, this is not sustainable and government and the people must seek ways to address the issue. The meaning and essence of education seem to have been lost on our youth and the time tested transmission of knowledge, moral values and character formation function of education is being tested and compromised.

Central to the issue is the quality of educational offering in Nigeria, the underlying causal issues of the declining quality, the level of disconnect of the educational offering to the changing needs of the country, and what can be done to alleviate the situation. Some endogenous problems such as quality of teaching, poor instructional methods; rote learning, maintenance of discipline, poor teaching aids, like subscription to educational magazines, continuous training and development of teachers, and lack of scholarship opportunities offered by the schools to extreme indigent students, were identified amongst others.

Some other factors which are considered exogenous were similarly identified including poor public education spend, lack of holistic and integrated education policy thrust, corruption and embezzlement at all levels of the education spectrum, industrial actions of teachers and strikes by students, poor teacher training, 
poor reward system and motivation. Others include culture and celebrated value system, poor research funding, lack of commercialization windows for local innovation and disconnect between industries and citadel of higher learning.

The construction of education outcomes is both a social and a private function that need to reflect the developmental needs of a society while also mirroring the mission of the institution. Outcomes assessment and assessment evaluation through the accreditation process needs to be reviewed to provide better assurance on the quality coming out of the HEI system. A clear cut role was cut for parents and other stakeholders in their parental and moral roles in the education process of shared moral values and transmission of the right values to society. The education scorecard of Nigeria revealed poor achievement in comparison to other African countries and DC on education outcomes, GDP spend on education, et al, while the global competitive ranking of Nigeria remain poor. We noted the discrimination against Nigerian HEI graduates in Nigeria by multinationals in Nigeria.

There appears to be a clear disconnect between the stylized benefits of education as a catalyst to economic development and the brand of education the country is serving its youth. The result is the production of unemployable youths with limited skills and requiring significant investment to retool for effective use in the market place. Unemployment is also an issue of growing concern coming out of the un-employability of the graduates. It has been suggested that entrepreneurial training, internship programs and career counselling be incorporated into the school curricula as a way to preparing the graduates for transition to the real world and to narrow the disconnection of the HEI with the developmental needs of the nation.

In the midst of these underlying causal factors of poor quality education in Nigeria, education continues to be run with business as usual attitude. The global trend is for public and private funding support for HEI and Nigeria cannot be isolated from the world. We noted that over $50 \%$ of the federal budget would be required to fund higher education and perhaps the total national budget if the quality education we desire is to be pursued. It is apparent government can no longer do it alone and the support and cooperation of the citizen is required in directing efforts to get the country back to the world education map. The socialization of education is history and all must have a paradigm shift. However, given citizen distrust of government on equity in appropriation of public funds, a middle ground between socialization and privatization of HEI system must be placed on the menu for consideration.

\section{Recommendations.}

The objective of the paper is to situate the dis-connection, importance, and means of addressing the education factor in the development agenda of Nigeria. Based on the issues raised in this commentary and in the conclusion, recommendations below would appear appropriate

1. Contextualization of educational learning methodologies and learning outcomes to the sociological and cultural state of the country to meet the needs and aspirations of the people. The HEI curriculum should focus on functional areas in need by the society. For example, Agricultural training should focus more on food preservation and elementary mechanisation processes that are more relevant to Nigeria's need. Technical manpower should be trained at all levels of HEI learning on agricultural methods to expand the frontiers of practical agricultural extension support services to farmers. Medical and Health training should focus more on areas as malaria and communicable diseases that is ravaging the continent rather than waiting for foreign solutions. Engineering and technical manpower training would do well if student training in design is laced with a good dose of practical and experiential learning in the areas of founding, fabrications and tooling so the intermediate mechanical devices required for industries and household uses could be developed and manufactured locally. No matter how incomparable to international standard, home-grown technological products would be a welcome relief for all and a march towards development. It should be noted that scientific knowledge is in the public domain and transcend national borders (IIEP, 2007). The accessibility and use of the knowledge however depends on the availability and quality of the human capital, thus the imperative to focus on high level quality training of manpower rather than the massifcation the country has subscribed to without concomitant quality.

2. The curriculum, teachingand assessment methodologies require restructuring to address rote memorisation as a means of learning and knowledge transmission. Deep learning and critical thinking capabilities need to be developed very early in our student which combined with an instilled culture of education as a life-long learning experience will produce a problem solving and ideas generation. Functionally, HEI must seek active means of engaging all stake holders in the continuous redesign of their curricula for relevance to society (city university, Seattle)

3. Promotion of faculty discipline, professionalism, and high standard of performance. Independent evaluation process of faculty by HEI stakeholders including student evaluation, administrative evaluation, and research 
and professional evaluation need to be instituted. A situation where a lecturer teaches and is not evaluated by students for teaching effectiveness allows laziness and low productivity in terms of preparation, delivery, feedback and self-improvement.

4. Recalibration of the accreditation process for better results. We idealized on several functions that the accreditation process is expected to perform but noted the rancorous relationship between the NUCandNBTE on the one side, the Universities and polytechnics on another side and the education ministry on the other side. The monopoly nature of the accreditation process, the methods of reporting, and the mandatory nature of the accreditation in comparison to the voluntary complexion of accreditation internationally, requires an overhaul for effectiveness. This would further drive a healthy, collaborative, open and transparent relationship with the education ministry. Both accreditor and ministry are organs of government.

5. A systematic national program aimed at the restoration of the dignity and self -esteem of HEI teachers must be convoked. When teachers regain their dignity and self-esteem, it is most likely thatthe level of selfmotivation and commitment would be enhanced for better productivity across board. Specifically, introduction of better emolument and competitive terms of service, performance driven work environment, respect for agreement with the teaching associations, provision of administrative and teaching support aids et al, will signal return of respect and recognition for the teaching profession. Sectorial reallocation of good hands is likely to result from this. Concomitantly, the uncommitted and bad eggs amongst the teachers should be weeded out of the profession for the full restoration of dignity to the profession.

6. Nutrition and health. Education is the child development from within and the growth can only be guaranteed when a child is well fed and healthy and free from diseases that could inhibit the physical and mental wellbeing. The government need to engage stakeholder at the basic schooling level to ensure the right mix of nutrition is guaranteed for the children while at the higher education level, relevant infrastructural and policy framework support may be introduced to enhanced nutritional value of students. Building of kitchenette in hostels, agricultural marts for vegetables produced by Agriculture department on campus, et al

7. Character formation function of education may be enhanced by government through several policy thrust including zero corruption policy, sustained public enlightenment program to schools, celebrating moral icons et al. A culture is the sum total of values transmitted from one generation to another and the government can,through its actions, signal a cultural transformation in society and work with parents to shape the values that are transmitted to the next generation.

8. A marshal Plan should be scripted for the educational system especially HEI to prosecute the catch-up plan to world standard for HEI. Higher education is both a public and private good and the funding requirement to meet the exigencies of national needs should be jointly funded by both the government and the private beneficiaries of higher education. Therefore, the program should be funded from a complementary onetime tax on corporate and private citizens as both groups stand out as beneficiaries of the education system.

9. In addition to the complementary onetime tax to supplement the catch up phase of development of the education infrastructural needs, a Sovereign education trust fund (SETF) should be established to replace the ETF. The SETF should get its seed fund and annual contribution from the National Sovereign fund in addition to the ETF funds which should be totally transferred to the SETF for management. The SETF should also be expected to actively engage and grow endowments from local and international sources. The trust deed establishing the SETF should be explicit on the purpose, responsibility and control of the fund and in all events private sector led.

10. The SETF should be given a mandate to show presence in the first 100 universities in the world and developing an educational hub in West Africa as a sustainable source of development and a foreign exchange earner within a time frame. The specific administrative configuration and collaboration between the fund and the HEI and the Education ministry must be well set out but the control over the funds must remain with the private sector led fund managers

11. Each HEI should be encouraged to pursue more vigorously endowment funds from its various stakeholders including alumni associations, corporate organisation and other alliance partners.

12. Each HEI should be encouraged to set up commercially viable forward and or backward integration businesses that ties in with the main vision of the HEI, and which can connect to the academic programs, 
For example, An agricultural business could provide apprenticeship and internship opportunities for agriculture students while also contributing to the food basket of the HEI environment, and augmenting the financial base of the HEI.

13. Discriminating pricing mechanism could meet the twin and often conflicting objectives of socialization and privatization of education. HE can no longer be free because the entire federal budget is unlikely to keep pace with the cost of funding qualitative HEI in Nigeria. Parents should share the burden of funding HEI. In order to unburden the poor and bring an all-inclusive educational opportunity to all, scholarships would be offered on select development fields necessary to spur accelerated development while all other fields of human endeavours would be made to pay school fees.

14. The curriculum should incorporate entrepreneurship training, internship, apprenticeship, and early career counselling to reduce the cost and pain of transition from school to active employment. It is estimated that less than $20 \%$ of graduates have appropriate training or are employable and the cost of conversion is steep for employers, and generally an impedance to productivity. Similarly, the less than $20 \%$ annual student intake by Nigeria's HEI is a challenge to attaining comparable higher education-population ratio estimated to be less than $10 \%$ against most developed countries at over $70 \%$. Since the battleground of development is the enlightened mind produced by the educational system, a deliberate policy to improve the annual HEI studentintake through private sector participation is non-negotiable. Government should begin to have the conversation on what manner of infrastructural and policy support framework it can offer to encourage increased private sector participation in HEI provision.

15. There is need to overhaul the administrative oversight function and regulatory regime over the establishment of HEI to encourage serious educationists and entrepreneurs. Private higher educational institutions growth rate have outpaced the public HEI growth rate worldwide and Nigeria must catch up with the rest of the world if the desired massification of higher education would stand any chance.

16. The ministry of education in conjunction with the communication ministry should evolve a framework to encourage a minimum e learning infusion into HEI pedagogic delivery and learning interactions. Overall, it ensures a cheaper means of higher education delivery, more active engagement between faculty and students, and amongst students thus upping the quality of exchange and learning. The plan could prescribe minimum standard for new institutions while a phase approach is recommended for established HEI. Government must therefore deliberately embark on a focused connection of HEI to better communication link including the land lines which are more stable and cheaper.

17. Finally, regional consolidation of leadership, programmatic reviews, and specialization of HEI offerings are recommended to achieve the twin objectives of cost containment and release of quality faculty to teaching and better effectiveness in the resource use by HEI.

\section{References}

[1]. Abayomi, A., Arenyeka, L (2014) Nigerians pay N160bn tuition on 71,000 children in Ghana.

[2]. Vanguard Newspaper on June 07, 2012 /in Education 2:00 am. Retrieved from http://www.vanguardngr.com/2012/06/nigerianspay-n160bn-tuition-on-71000-children-in-ghana/\#sthash.CiSfihNB.dpuf

[3]. Adeogun, A.A, Subair, S.T, Osifila, G.T (2009). Deregulation of University Education in Nigeria:

[4]. Problems and Prospects. Florida Journal of Educational Administration \& Policy. Volume 3, Issue 1 Retrieved from http://education.ufl.edu/fjeap/files/2011/01/FJEAP Winter-2009 3-1 Adeogun FINAL.pdf

[5]. Adeyemi, T.O (2011) Financing of education in Nigeria: An analytical review. Retrieved fromhttp://www.scihub.org/AJSMS/PDF/2011/3/AJSMS-2-3-295-303.pdf

[6]. Akinsanya, O.O. (2007).

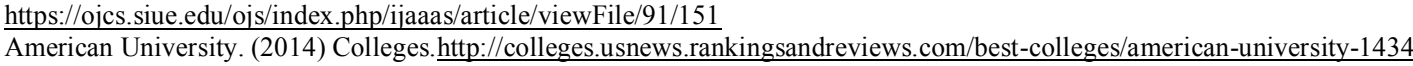

[7]. American University. (2014) Colleges.http://colleges.usnews.rankingsandreviews.com/best-col

[9]. Nigerian Universities. Retrieved from http://www.afriheritage.org/publications/PPP\%20in\%20Infrastructural\%20Development.pdf

[10]. ASSU (2009) Agreement between the federal government of Nigeria (FGN) and the academic staff unionOf universities (ASUU) January 2009. Retrieved from http://asuu-ng.org/test/2009agreement1.pdf

[11]. AUT (2005) Packing them in -The student-to-staff ratio in UK higher education. Retrieved from http://www.ucu.org.uk/media/pdf/c/j/ssr_packingthemin.pdf

[12]. Avgerou, C. (2010) Discourses on ICT and Development: Research Article. Information Technologies

[13]. And International $\quad$ Development. $\quad$ Vol. $6 . \quad$ No $\quad 3 . \quad 2010 . \quad$ Retrieved http://web.a.ebscohost.com/ehost/pdfviewer/pdfviewer?vid=11\&sid=4cf75e90-f23e-4fa4-bdb595e9cf2cafba $\% 40$ sessionmgr4001\&hid $=4214$

[14]. Babalola, A. (2014) School fees clarification for returning undergraduate students 2013/2014

[15]. Academic session. Retrieved from http://www.abuad.edu.ng/en/component/content/article/9-uncategorised/453-school-feesclarification-for-returning-undergraduate-students-2013-2014-academic-session 
[16]. Babarinde, K. (2012) Evolution, Development, challenges, and Prospect of Higher Education In Nigeria. www.trustafrica.org/.../workshops-and-convenings?...education...nigeria

[17]. Bailey, T., Cloete, N.,Pillay, P. (2012). Universities and economic development in Africa: A case study of the University of Ghana. Retrieved from http://chet.org.za/files/uploads/reports/Case\%20Study\%20-\%20Ghana\%20and\%20University\%20of\%20Ghana.pdf

[18]. Bandura, A. (1997). Self-Efficacy: The exercise of control (PowerPoint Slides) Retrieved from http://www.uky.edu/ eushe2/quotations/bandura.html and http://www.emory.edu/EDUCATION/mfp/Bandura

[19]. Good-Practice-in-Counselling-and-Psychotherapy_1276615182.pdf

[20]. Bell, B.D. (2006) Texas community college funding structure: closing the gaps while assessing the attitudes and perceptions of community college senior administrators. Retrieved from https://digital.library.txstate.edu/bitstream/handle/10877/3535/fulltext.pdf

[21]. Brühlmeier, A. (2010) Head, Heart and Hand Education in the Spirit of Pestalozzi. http://www.pestalozziworld.com/images/HeadHeartandHand.pdf

[22]. Caine, R., N., Caine G., McClintic, C., Klimek, K. (2008). 12 Brain/Mind Learning Principles in

[23]. Action. The Field Book for Making Connections, Teaching, and the Human Brain. Foreword by Arthur L. Costa 2nd Edition. ISBN 1-4129-0984-8

[24]. CHEA. (2014). Accreditation in Higher Education. Retrieved fromhttp://www.chea.org/directories/regional.asp

[25]. Chikwem, R. (2006). The state of Higher education in Nigeria. Retrieved from http://www.dawodu.com/chikwem3.htm

[26]. CIA (2014) the world Fact book. Field Listing: literacy. Retrieved from https://www.cia.gov/library/publications/the-worldfactbook/fields/2103.html

[27]. City University Seattle (2012). City University Seattle School of Management: 2012 comprehensive self-study prepared for the Accreditation council for business schools and programs (ACBSP).

[28]. Combs, J. (2010) Writing your own Educational Philosophy. Retrieved fromhttp://www.edulink.org/portfolio/philosophies.htm

[29]. Dangcalam, C.M. (2011) Poverty: a hindrance to a good education http://www.sunstar.com.ph/davao/opinion/2011/06/11/dangcalan-poverty-hindrance-good-education-160658

[30]. European Commission (2008) Higher Education Governance in Europe. Policies, structures, funding and academic staff. ISBN 978$\begin{array}{llcl}92-79-08524-6 . & \text { DOI } & 10.2766 / 29900 . & \text { Retrieved }\end{array}$ fromhttp://eacea.ec.europa.eu/education/eurydice/documents/thematic reports/091EN.pdf

[31]. Gachie, J. (2013) Universities in Kenya (Softkenya) Retrieved from http://softkenya.com/university/

[32]. Gylfason, T. (2001) Natural resources, education, and economic development. European Economic

[33]. Review. Volume 45, Issues 4-6. May 2001, Pages 847-859. DOI: 10.1016/S0014-2921(01)00127-1

[34]. Hanushek, E.A., Wößmann, L. (2007) Role of education Quality for economic growth. https://openknowledge.worldbank.org/bitstream/handle/10986/7154/wps4122.pdf?sequence=1

[35]. HEFCE (2010). The higher education workforce framework 2010: overview report. Retrievedfromhttps://www.hefce.ac.uk/media/hefce/content/pubs/2010/201005/10 05.pdf

[36]. IIEP (2007) Higher education and development. International institute for educational planning Newsletter. Vol. XXV, $\mathrm{N}^{\circ} 1$, January-March 2007. http://www.unesco.org/iiep ISBN 1564-2556

[37]. Institute of educational sciences (2013) Fast facts: Educational institutions in the US (US department of education statistics) Retrieved from http://nces.ed.gov/fastfacts/display.asp?id=84

[38]. Kigotho, W. (2014). The education goal- Africa's unfinished business. https://bevond2015.acu.ac.uk/submissions/view?id=82

[39]. Kolawole, Y. (2014). Efficient taxation can boost Nigeria's education finance by N2.08trn - UNESCO -

[40]. The Vanguard Newspaper Retrieved fromhttp://www.vanguardngr.com/2014/03/efficient-taxation-can-boost-nigerias-educationfinance-n2-08trn-unesco/\#sthash.IRsUlHuD.dpuf

[41]. Kolb, D.A. (1984) Experiential learning: experience as the source of learning and development http://academic.regis.edu/ed205/Kolb.pdf

[42]. Lee Kuan Yew, (2000). From third World to First: The Singapore story: 1965-2000. 1-95. ISBN 0-06-019776-5

[43]. Madon, S. (2000). The Internet and Socio-economic development: Exploring the interaction. LSE. Retrievedfromhttp://citeseerx.ist.psu.edu/viewdoc/download?doi=10.1.1.108.9673\&rep=rep1\&type=pdf

[44]. Montgomery (2008). Montgomery educational consulting. Students to faculty ratios: what do these statistics mean? http://greatcollegeadvice.com/student-to-faculty-ratios-what-do-these-statistics-mean-part-i/

[45]. Moody's Investors Service (2013) US Higher Education Outlook Negative in 2013

[46]. Revenue Pressure on All Fronts Intensifies Need to Grapple with Traditional Cost Structure. Retrieved from http://www.marquette.edu/budget/documents/USHigherEducationOutlookNegativein2013.pdf

[47]. National Board for technical education, (2013). About NBTE. Retrieved from http://www.nbte.gov.ng

[48]. National university commission, (2013) about us and online accreditation. http://www.nuc.ed.ng

[49]. OECD Factbook. (2011-2012) Economic, Environmental and Social Statistics. Public and private expenditure on

[50]. Education. Retrieved from h ttp://www.oecdilibrary.org/docserver/download/3011041ec089.pdf?expires=1401468169\&id=id\&accname=guest\&checksum=11 A09453466A067 0A5DD0AA53B1E792D

[51]. Okojie, J.A. (2013) Innovative Funding in the Nigerian University System. Retrieved from http://www.unilorin.edu.ng/downloads/Okojie-Innovative\%20Funding.ppt

[52]. Rosado, C. (1997). Paradigm shifts and stages of societal change: a descriptive model. Retrieved from http://rosado.net/pdf/Paradigms.pdf

[53]. Rosado, C. (2000) The Meaning of Education or Why Do We Do What We Do? http://www.rosado.net/pdf/Meaning of Education Art.pdf

[54]. Southern association of colleges and schools commission on colleges (SACS COC), (2012). Accrediting standards. Retrieved from http://www.sacscoc.org/principles.asp

[55]. Shu'ara, J. (2010) Higher education statistics: Nigeria experience in data collection. Paper presented at the

[56]. UNESCO Institute of Statistics Workshop on Education Statistics in Anglophone Countries, Windhoek 17th - 21st October 2010 by the Director, Tertiary Education Federal Ministry of Education, Abuja. Retrieved from http://www.uis.unesco.org/StatisticalCapacityBuilding/Workshop\%20Documents/Education\%20workshop\%20dox/2010\%20Windh oek\%20-Regional $\% 20$ Workshop $\% 20$ on $\% 20$ Education $\% 20$ Statistics $\% 20$ for $\% 20$ South $\% 20$ and $\% 20$ Eastern $\% 20$ Africa/NIGERIAHigher\%20education\%20statistics-\%20National\%20experience.pdf

[57]. Singh, R, (2013) Research communication on Rabindranath Tagore's contribution in education. VSRD

[58]. International Journal of Technical \& Non-Technical Research, Vol. IV Issue VIII August 2013 / 201e-ISSN: 0976-7967, p-ISSN: 2319-2216. 
http://www.vsrdjournals.com/vsrd/Issue/2013_08_August/Web/7_Ravi_Singh_2520_Research_Communication_VSRDIJTNTR_A ugust 2013.pdf

[59]. Udoh, A.O (2013) Alternative Sources of Funding University Education in Nigeria. Retrieved from www.ajol.info/index.php/afrrev/article/download/41067/8492

[60]. University World Wide News (2013) Academic shortage deepens as student numbers soar. Retrieved from http://www.universityworldnews.com/article.php?story=20130329101026666

[61]. US Embassy (2013) Nigeria Education Fact Sheet United States Embassy in Nigeria. Retrieved from http://photos.state.gov/libraries/nigeria/487468/pdfs/JanuaryEducationFactSheet.pdf

[62]. Yero, J.L. (2002). The meaning of Education. Teacher's Mind Resources: http://www.stoa.org.uk/topics/education/The $\% 20$ Meaning\%20of $\% 20$ Education.pdf

[63]. UNESCO (1990) meeting basic learning needs: A vision for the 1990. World Conference on Education for All. http://unesdoc.unesco.org/images/0009/000975/097552e.pdf

[64]. UNESCO (2009) Trends in Global Higher Education: Tracking an Academic Revolution. A Report prepared for

[65]. the World Conference on Higher Education. Philip G. Altbach. Liz Reisberg. Laura E. Rumbley. http://www.uis.unesco.org/Library/Documents/trends-global-higher-education-2009-world-conference-en.pdf

[66]. UNESCO (2011) Financing Education in Sub-Saharan Africa: Meeting the challenges of Expansion, Equity and Quality. http://www.uis.unesco.org/Library/Documents/Finance EN web.pdf

[67]. UNESCO (2013). Regional Thematic Consultation of Western European and North American States

[68]. (Group I Countries) on $\quad$ Education the

Agenda.http://unesdoc.unesco.org/images/0022/002274/227459e.pdf

[69]. UNESCO (2001) http://www.unesco.org/education/gmr download/chapter2.pdf 